\title{
PERAN EMOSI MEMEDIASI PENGARUH STORE ATMOSPHERE TERHADAP PERILAKU PEMBELIAN DI KARAKTER KOPI
}

\author{
Putu Gde Krisnandadifa Dharma P. ${ }^{1}$ \\ Ni Made Wulandari Kusumadewi ${ }^{2}$
}

\author{
${ }^{1,2}$ Fakultas Ekonomi dan Bisnis Universitas Udayana, Bali, Indonesia \\ e-mail: krisnanda_95@yahoo.co.id
}

\begin{abstract}
ABSTRAK
Tujuan dari penelitian ini adalah untuk mengetahui peran emosi memediasi pengaruh store atmosphere terhadap perilaku pembelian di karakter kopi. Penelitian ini dilakukan di Karakter Kopi Denpasar. Jumlah sampel dalam penelitian ini sebanyak 102 responden. Pengumpulan data dilakukan melalui penyebaran kuesioner dengan teknik analisis path (analisis jalur). Berdasarkan hasil analisis ditemukan bahwa store atmosphere berpengaruh positif dan signifikan terhadap emosi positif konsumen. Emosi positif berpengaruh positif terhadap perilaku pembelian konsumen. Store atmosphere berpengaruh positif dan signifikan terhadap perilaku pembelian. Emosi positif berpengaruh positif dan signifikan dalam memediasi store atmosphere terhadap perilaku pembelian. Untuk meningkatkan pembelian konsumen yang datang ke Karakter kopi, dapat dilakukan dengan cara memperahankan dan meningkatkan faktor exterior terutama dalam suasana lingkungan dan produk dari Karakter Kopi itu sendiri, bila faktor ini ditingkatkan maka memungkinkan penciptaan emosi yang dapat dirasakan oleh konsumen ini positif sehingga mampu mempengaruhi perilaku dari para konsumen yang datang.
\end{abstract}

Kata Kunci: emosi, store atmospher, perilaku pembelian

\begin{abstract}
The purpose of this study was to determine the role of emotion mediate the influence of store atmosphere on buying behavior in coffee character. This research was conducted at Karakter kopi Denpasar. The number of samples in this study were 102 respondents. Data collection was done by distributing questionnaires with path analysis technique (path analysis). Based on the results of the analysis found that store atmosphere has a positive and significant impact on consumer positive emotions. Positive emotions have a positive effect on consumer buying behavior. Store atmosphere has a positive and significant effect on buying behavior. Positive emotions have a positive and significant influence in mediating store atmosphere on buying behavior. To increase consumer purchases that come to the Karakter kopi, can be done by maintaining and improving the exterior factor, especially in the atmosphere and products of the Karakter kopi itself, when this factor is improved it allows the creation of positive emotions that is perceived by consumers therefore it can affect the behavior of up coming consumers.
\end{abstract}

Keywords: emotion, store atmospher, buying behavior 


\section{PENDAHULUAN}

Perkembangan bisnis coffee shop di Bali sangat beranekaragam serta memiliki daya tarik dan konsep yang berbeda. Bisnis coffee shop itu sendiri banyak digeluti oleh kaum-kaum muda atau remaja yang ada di Bali. Menurut Marsum (2005) Coffee shop adalah tempat untuk makan dan minum sajian cepat saji dan menyuguhkan suasanan santai atau tidak resmi, selain itu juga merupakan suatu tipe dari restoran yang biasanya menyediakan tempat duduk didalam dan diluar restoran. Menu pada coffee shop pada umumnya lebih sedikit dari restoran. Keberadaan coffee shop atau kedai kopi pada masyarakat menjadikan coffee shop sebagai tempat untuk menghabiskan waktu luang maupun hangout, maraknya perkembangan coffee shop atau kedai kopi di kota-kota besar membuat gaya hidup masyarakat menjadi lebih mengikuti kebudayaan Barat seperti Amerika dan Eropa.

Bisnis coffee shop mulai memasuki Indonesia sekitar tahun 2000-an, yang memenuhi kebutuhan fungsional akan tetapi mengarah juga ke kebutuhan emosional. Para orang tua dan remaja memilih coffee shop untuk bersantai setelah bekerja atau hanya untuk bersosialisai dengan teman-teman berkumpul bersama. Gaya hidup masyarakat kota sudah berubah masyarakat memilih coffee shop tidak hanya untuk menikmati kopi akan tetapi menikmati suasana dari coffee shop yang mereka kunjungi untuk bersosialisai.

Kopi merupakan minuman yang banyak disukai oleh banyak kalangan mulai dari tua sampai dengan remaja bahkan ada pula anak-anak. Walaupun menyeduh kopi dapat dilakukan sendiri di rumah, akan tetapi duduk di coffee shop memang 
memberikan suasana berbeda. Selain dari variasi menu, kebutuhan untuk bersosialisasi menjadi alasan yang kuat mengapa begitu banyak orang menyukai tempat berkumpul yang satu ini. Maka tak heran, puluhan bahkan ratusan kedai kopi membanjiri Bali sejak beberapa tahun belakangan.

Coffee shop raksasa yang notabene adalah berasal dari negeri Paman Sam juga mulai menjamur di Indonesia. Hal ini memang terjadi karena kebiasaan minum kopi tidak hanya kebutuhan untuk minum kopi saja, akan tetapi untuk keperluan sosialisasi seperti halnya meeting kantor ataupun berbisnis yang mulai banyak dilakukan di café ataupun coffee shop atau memang mereka hanya mengunjungi coffee shop untuk keperluan berkumpul bersama rekan ataupun saudara.

Perkembangan kedai kopi di kota Denpasar dapat dirasakan keberadaannya, baik kedai kopi yang berbentuk franchise asing ataupun lokal. Perkembangan globalisasi membuat konsep atau sudut pandang coffee shop atau kedai kopi itu berubah, yang dulu merupakan suatu tempat yang dijadikan pesinggahan saat berkendara jauh menjadi sebuah tempat untuk menghabiskan waktu untuk bersosialisasi. Banyaknya keberadaan coffee shop atau kedai kopi itu membuat persaingan yang cukup ketat pada usaha coffee shop sehingga memaksa perusahaan untuk memperhatikan strategi untuk meningkatkan maupun mempertahankan profit mereka dengan mampu membaca perilaku pembelian konsumen khususnya di kota Denpasar.

Rata-rata coffee shop saat ini umumnya mempunyai desain yang modern dan minimalis. Dengan sentuhan interior yang minimalis dan sebuah open bar 
dapat membuat pengunjung betah berlama - lama. Berbeda dari coffee shop lainnya, Karakter Kopi membawa karakternya sendiri. Rumah panggung yang bediri kokoh di Jalan Tukad Barito Timur no. 99 Renon, membuat rasa penasaran muncul. Halaman yang luas dengan kursi dan meja yang antik menghiasi bagian depan dari Karakter Kopi.

Ketika masuk, konsumen harus menaiki rumah panggung terlebih dahulu untuk memesan kopi. Disini pengunjung tidak akan didatangi oleh pelayan untuk menyuguhkan menu. Pengunjung sendiri yang harus datang ke meja bar atau kasir ketika ingin memesan. Konsep self service inilah yang membedakan Karakter Kopi dari coffee shop biasanya. Hiasan dinding dan furniture lawas terpajang disetiap sudut Karakter Kopi, bahkan ada juga foto presiden beserta wakil presidennya. Semua konsep yang ada di Karakter Kopi memang sengaja dibangun sedemikian rupa agar pengunjung dapat kembali mengenang masa lalu.

Karakter kopi selalu ramai didatangi pengunjung setiap harinya, selain konsep dan store atmosphere yang dimiliki oleh Karakter kopi yang mampu menarik perhatian dari para pengunjung. Pada dasarnya gaya hidup atau lifestyle masyarakat kota Denpasar yang sudah berubah, tidak hanya menjadikan Karakter kopi sebagai tempat yang menjual kopi saja akan tetapi menjadikan Karakter kopi sebagai tempat ajang untuk bersosialisasi bersama teman-teman, dan juga mencari inspirasi untuk mengerjakan pekerjaan kantor atau sekolah. Selain itu lokasi dari Karakter kopi sendiri yang membuat para pengunjung datang, karena bagi sebagian orang yang datang menganggap lokasi dari Karakter kopi cukup strategis dan mudah untuk mencari lokasi dari Karakter Kopi tersebut. 
Perkembangan bisnis dibidang kopi membuat setiap kedai kopi harus membuat sebuah terobosan untuk memikat pelanggan salah satu nya yaitu dengan memperhatikan store atmosphere yang juga mampu menjadi pembeda antara kedai kopi satu dengan yang lain. Wakefield \& Baker (1998) membuktikan bahwa probabilitas pelanggan bertahan lebih lama di toko meningkat karena stimulus atmosfer. Store atmosphere sebagai sarana komunikasi dapat berdampak positif jika dibuat sedemikian menarik dan juga dapat berdampak negatife jika tidak diperhatikan.

Store atmosphere merupakan unsur senjata lain yang dimiliki toko. Setiap toko mempunyai tata letak fisik yang memudahkan atau menyulitkan pembeli untuk berputar-putar didalamnya. Setiap toko mempunyai penampilan. Toko harus membentuk suasana terencana yang sesuai dengan pasar sasarannya dan yang dapat menarik konsumen untuk membeli. Penampilan toko memposisikan toko dalam benak konsumen (Mowen dan Minor, 2002).

Proses penciptaan store atmosphere adalah kegiatan merancang lingkungan pembelian dalam suatu toko dengan menentukan karakteristik toko tersebut melalui pengaturan dan pemilihan fasilitas fisik toko dan aktivitas barang dagangan. Lingkungan pembelian yang terbentuk melalui komunikasi visual, pencahayaan, warna, musik dan wangi-wangian, dirancang untuk menghasilkan pengaruh atau respon emosional dan persepsi khusus dalam diri konsumen sehingga bersedia melakukan pembelian serta kemungkinan meningkatkan pembeliannya (Utami, 2006). Store atmosphere memiliki banyak elemen-elemen mulai dari store exterior, general interior, store layout, interior display. Elemen- 
elemen tersebut dapat mempengaruhi emosi dari para pembelinya yang sedang menikmati makanan atau minuman di toko tersebut.

Emosi merupakan suatu perasaan yang dimiliki oleh seseorang yang dapat mempengaruhi perilaku dari seseorang tersebut. Menurut Goleman (2000: 411) emosi merujuk pada suatu perasaan dan pikiran yang khas, suatu keadaan biologis dan psikologis dan serangkaian kecenderungan untuk bertindak. Emosi pada dasarnya adalah dorongan untuk bertindak.

Sedangkan Matilla dan Holbrook dalam Feng et al. (2008) menyatakan bahwa "consumer emotion is formed by mutual interactions of the store and the consumer". Emosi terbentuk dari interaksi antara toko dengan konsumen. Jadi hubungan antara toko dengan konsumen akan menciptakan emosi seseorang. Dari beberapa teori diatas dapat disimpulkan bahwa emosi merupakan perasaan yang ada dalam diri seseorang yang dapat mempengaruhi perilaku kita termasuk perilaku dalam melakukan pembelian

Konsumen akan merasa puas terhadap lingkungan suatu suasana toko saat konsumen menghabiskan lebih banyak waktu di toko tertentu yang akan berdampak kepada emosi dikarenakan adanya rangsangan lingkungan yang menyenangkan. Secara tidak langsung, suasana nyaman dari atmosfir toko dapat mempengaruhi emosi konsumen. Seperti penelitian sebelumnya yang dilakukan oleh Feng et al. (2008), Anggoro, (2012), Sukma dkk. (2012), Pragita (2013), Setiawan (2015), Dewi (2015) Tujungsari dkk. (2016), Helmefalk dan Hultēn. (2017) bahwa Store Atmosphere berpengaruh secara signifikan terhadap emosi. 
Vilnai et al. (2006) dalam Setiawan (2015) mengatakan, bahwa emosi berpengaruh kuat terhadap kepuasan konsumen. Menurut Gardner dalam Feng et al. (2008) mengatakan, bahwa emosi merupakan keadaan internal manusia yang ringan dan sementara yang umumnya dibentuk oleh persepsi subyektif.

Perilaku pembelian adalah tindakan konsumen sebelum memutuskan untuk membeli suatu produk yang mereka butuhkan, sehingga dalam prosesnya ada beberapa perilaku yang dapat dilihat, apakah calon konsumen tertarik akan produk-produk dari toko tersebut dan apakah konsumen merasa nyaman melakukan proses pembelian di toko tersebut. Kotler dan Keller (2012: 173) mendefinisikan Perilaku konsumen adalah studi tentang bagaimana individu, kelompok, dan organisasi memilih, membeli, menggunakan dan membuang barang, jasa, gagasan atau pengalaman untuk memenuhi kebutuhan dan keinginan mereka.

Dalam melaksanakan proses perilaku pembelian, secara umum konsumen melalui tiga tahapan yaitu, tahap pertama adalah aktivitas perusahaan dalam memasarkan produk diiringi pemberian rangsangan yang dapat mempengaruhi persepsi dari konsumen, misalnya melalui konsep 4P atau Marketing Mix baik secara parsial maupun komprehensif. Tahap kedua, berdasarkan aktivitas dan rangsangan dalam kegiatan pemasaran, semua input yang diterima oleh konsumen tersebut akan diolah sedemikian rupa berdasarkan karakteristik dan lingkup pengambilan keputusan pembelian oleh individu, misalnya dipengaruhi oleh faktor-faktor seperti budaya, kelas sosial, kepribadian dan psikologi. 
Tahap terakhir, adalah tahap pembuatan keputusan pembelian, dimana bisa dipengaruhi oleh tingkat kebutuhan akan produk/jasa, keputusan terhadap merk, dan pemilihan pemasok, pemilihan waktu dan jumlah pembelian produk/jasa, serta jenis produknya dan faktor demografi. Seperti penelitian yang dilakukan sebelumnya oleh Feng et al. (2008), Setiawan (2015), Makarawung et al. (2014), Abednego (2011), bahwa emosi berpengaruh signifikan terhadap perilaku pembelian. Berdasarkan hasil wawancara yang dilakukan kepada 30 narasumber, 12 diantaranya mengatakan merasa senang saat membeli produk di Karakter kopi sedangkan 18 di antaranya mengatakan tidak merasa senang saat membeli produk di karakter kopi di karenakan menurut sebagian narasumber harga dari produk di karakter kopi cukup mahal.

Selain emosi yang mempengaruhi perilaku pembelian ada juga variable yang mempengaruhi perilaku pembelian yaitu store atmosphere, menurut hasil penelitian sebelumnya yang dilakukan oleh Feng et al. (2008), Helmefalk dan Hultēn. (2017), Andersson et al. (2012) bahwa store atmosphere berpengaruh positif terhadap perilaku pembelian konsumen.

Melihat bahwa adanya hubungan dari ketiga variable tersebut yang dimana “emosi memediasi pengaruh store atmosphere terhadap perilaku pembelian" dengan demikian penelitian dilakukan pada Karakter Kopi coffee shop di kota Denpasar. Dari sekian banyak kedai atau coffee shop yang ada di Denpasar, Karakter Kopi ini memiliki suatu keunikan dibanding kedai kopi lainnya, mulai dari suasana yang sederhana namun memiliki konsep toko mereka tersendiri 
sampai dengan minuman maupun makan yang mereka sajikan memiliki karakternya masing-masing.

Berdasakan latar belakang yang telah diuraikan, maka dilakukan penelitian untuk mengetahui apakah emosi memediasi pengaruh store atmosphere terhadap perilaku pembelian konsumen pada coffee shop Karakter Kopi. Pemaparan mengenai kejadian yang telah dibahas sebelumnya menunjukan bahwa perilaku konsumen khususnya pada perilaku pembelian (Y) yang dimediasi oleh variable emosi (M) dan yang dipengaruhi oleh variable Store Atmosphere (X).

Store atmosphere merupakan unsur senjata lain yang dimiliki toko. Setiap toko mempunyai tata letak fisik yang memudahkan atau menyulitkan pembeli untuk berputar-putar didalamnya. Setiap toko mempunyai penampilan. Toko harus membentuk suasana terencana yang sesuai dengan pasar sasarannya dan yang dapat menarik konsumen untuk membeli. Penampilan toko memposisikan toko dalam benak konsumen (Mowen dan Minor,2002). Proses penciptaan Store Atmosphere adalah kegiatan merancang lingkungan pembelian dalam suatu toko dengan menentukan karakteristik toko tersebut melalui pengaturan dan pemilihan fasilitas fisik toko dan aktifitas barang dagangan. Lingkungan pembelian yang terbentuk, melalui komunikasi visual, pencahayaan, warna, musik dan wangi-wangian, tersebut dirancang untuk menghasilkan pengaruh atau respon emosional dan persepsi khusus dalam diri konsumen sehingga bersedia melakukan pembelian serta kemungkinan meningkatkan pembeliannya (Utami, 2006). 
Perilaku pembelian adalah tindakan konsumen sebelum memutuskan untuk membeli suatu produk yang mereka butuhkan, sehingga dalam prosesnya ada beberapa perilaku yang dapat dilihat, apakah calon konsumen tertarik akan produk-produk dari Toko tersebut dan apakah konsumen merasa nyaman melakukan proses pembelian di toko tersebut. Menurut Belch and Belch (2012: 114) menyatakan Perilaku konsumen dapat didefinisikan sebagai proses dan aktivitas yang dilakukan orang saat mencari, memilih, membeli, menggunakan, mengevaluasi, dan membuang produk dan layanan sehingga dapat memenuhi kebutuhan dan keinginan mereka. Kotler dan Keller (2012: 173) mendefinisikan Perilaku konsumen adalah studi tentang bagaimana individu, kelompok, dan organisasi memilih, membeli, menggunakan dan membuang barang, jasa, gagasan atau pengalaman untuk memenuhi kebutuhan dan keinginan mereka.

Menurut penelitian yang dilakukan oleh Feng et al. (2008), Helmefalk dan Hultēn. (2017), Mishra et al. (2014), Tunjungsari dkk. (2016), Pragita dkk. (2013), Sukma dkk. (2012), Madjid (2014), menenmukan bahwa Store Atmosphere berpengaruh positif dan signifikan terhadap emosi. Berdasarkan kejadian impiris dan penelitian sebelumnya, dapat dibangun hipotesis sebagai berikut:

$\mathrm{H}_{1}$ : Store Atmosphere berpengaruh positif dan signifikan terhadap emosi

Menurut penelitian yang dilakukan oleh Feng et al. (2008), Setiawan (2015), Makarawung dkk. (2014), menemukan bahwa emosi berpengaruh positif 
dan signifikan terhadap perilaku pembelian. Bedasarkan kejadian impiris dan penelitian sebelumnya dapat dibangun hipotesis sebagai berikut:

$\mathrm{H}_{2}$ : Emosi berpengaruh positif dan signifikan terhadap perilaku pembelian

Menurut penelitian yang dilakukan oleh Feng et al. (2008), Helmefalk dan Hultēn. (2017), Mishra et al. (2014), Andersson et al. (2012), Fuad (2010). menemukan bahwa Store Atmosphere berpengaruh positif dan signifikan terhadap perilaku pembelian. Bedasarkan kejadian impiris dan penelitian sebelumnya dapat dibagun hipotesis sebagai berikut.

$\mathrm{H}_{3}$ : Store Atmosphere berpengaruh positif dan signifikan terhadap perilaku pembelian

Menurut Yoo et al. (1998) dalam Feng et al. (2008:99) mengatakan bahwa "A plethora of research has confirmed the role of emotion as an important mediator between Store Atmosphere and consumer behavior". Kebanyakan dari penelitian telah menerima peran emosi sebagai faktor penting sebagai mediator antara atmosfer toko dan perilaku pembelian, Sherman et al. (1997), Madjid (2014). Menemukan bahwa emosi berpengaruh positif dan signifikan memediasi pengaruh store atmosphere terhadap perilaku pembelian. Bedasarkan kejadian impiris dan penelitian sebelumnya dapat di bangun hipotesis sebagai berikut.

$\mathrm{H}_{4}$ : Emosi berperan positif dan signifikan memediasi pengaruh Store Atmosphere terhadap perilaku pembelian

\section{METODE PENELITIAN}

Lokasi penelitian ini dilakukan di Karakter Kopi. Lokasi ini dipilih karena, Karakter Kopi memiliki suasana toko atau Store Atmosphere yang dapat mengundang para konsumen datang dan berkumpul disana. Hal ini mempermudah 
dalam melihat seberapa besar pengaruh store atmosphere dan perilaku pembelian konsumen yang dimediasi oleh emosi.

Variabel penelitian adalah segala sesuatu yang berbentuk apa saja yang ditetapkan oleh peneliti untuk dipelajari sehingga diperoleh informasi tentang hal tersebut, kemudian ditarik kesimpulan. Adapun variabel yang diteliti dalam penelitian ini adalah. Store Atmosphere (X), Emosi (M) dan Perilaku pembelian (Y). adapun indicator dari masing-masing variabel ditampilkan dalam Tabel $1 \mathrm{di}$ bawah ini:

Tabel 1.

\section{Indikator Variabel}

\begin{tabular}{|c|c|c|}
\hline Variabel & Indikator & Sumber \\
\hline $\begin{array}{l}\text { Store } \\
\text { Atmosphere } \\
\text { (X) }\end{array}$ & $\begin{array}{l}\text { 1.Exterior Factor } \\
\text { Bagunan luar (X1) } \\
\text { Suasana lingkungan (X2) } \\
\text { 2.Interior Factor } \\
\text { Kebersihan (X3) } \\
\text { Musik (X4) } \\
\text { 3.Design and layout } \\
\text { Fasilitas (X5) } \\
\text { Tata letak (X6) } \\
\text { 4.Display } \\
\text { Tampilan informasi (X7) } \\
\text { Tampilan produk (X8) } \\
\text { 5.Paricipant } \\
\text { Penampilan karyawan (X9) } \\
\text { Sikap karyawan (X10) }\end{array}$ & Turly dan Miliman (2000:195) \\
\hline Emosi & 1.Perasaan senang (M1) & Setiawan (2015) dan Feng et al. (2008) \\
\hline (M) & $\begin{array}{l}\text { 2.Perasaan takjub (M2) } \\
\text { 3.Kepuasan (M3) } \\
\text { 4.Ketertarikan (M4) }\end{array}$ & \\
\hline $\begin{array}{l}\text { Perilaku } \\
\text { pembelian } \\
\text { (Y) }\end{array}$ & $\begin{array}{l}\text { 1.Memilih produk (Y1) } \\
\text { 2.Bertahan dalam toko (Y2) } \\
\text { 3.Pembelian berulang (Y3) }\end{array}$ & Setiawan (2015) dan Feng et al. (2008) \\
\hline
\end{tabular}

Sumber: Data diolah, 2018

Populasi dalam penelitin ini adalah seluruh pelanggan/pengunjung Karakter

Kopi. Sampel dalam penelitian ini adalah konsumen Karakter Kopi yang pernah 
mengkonsumsi produk Karakter Kopi lebih dari sekali dalam kurun waktu satu bulan. Penentuan sampel penelitian ini menggunakan metode non - probability sampling yakni teknik pengambilan sampel yang tidak memberi peluang / kesempatan yang sama bagi setiap unsur atau anggota populasi untuk dipilih menjadi sampel (Sugiyono, 2017: 85). Teknik non probability sampling yang dipilih adalah purposive sampling yaitu teknik penentuan sampel dengan pertimbangan kriteria tertentu.

Metode pengumpulan data untuk penelitian ini adalah dengan menggunakan metode survey yakni dengan kuesioner. Kuesioner disebarkan pada seputaran wilayah Kota Denpasar dan pengisiannya di dampingi oleh peneliti. Pengukuran atas jawaban dari responden diukur dengan menggunakan skala Likert. Teknik analisis data yang digunakan dalam penelitian ini adalah teknik analisis jalur (path analysis). Teknik analisis jalur ini dapat didefinisikan sebagai perluasan dari analisis linier berganda dalam memperkirakan hubungan kausalitas antara yang telah ditetapkan berdasarkan teori. Analisis jalur digunakan untuk menentukan hubungan 3 variabel atau lebih dalam mengkorfimasi dan menolak hipotesis.

\section{HASIL PENELITIAN DAN PEMBAHASAN}

Jumlah responden dalam penelitian ini adalah 102 orang. Responden yang memberikan tanggapan untuk kuesioner dari penelitian ini telah memenuhi kriteria-kriteria yang telah ditetapkan dalam kriteria responden penelitian yang diantaranya berdomisili di Kota Denpasar, pernah mengkonsumsi produk karakter kopi lebih dari sekali dalam kurun waktu satu bulan dengan pendidikan minimal SMA/sederajat. 
Responden pada penelitian di Karakter Kopi dominan berusia 22 sampai 26 tahun, dengan persentase sebesar 43,10 persen. Hal ini menandakan konsumen usia 22 sampai 26 tahun lebih memilih membeli produk yang dimiliki oleh Karakter Kopi karena pada usia 22 sampai 26 tahun kebanyakan responden memiliki kebiasaan meminum kopi dan berkumpul, bersosialisasi dengan temanteman.

Di lihat dari segi jenis kelamin, responden didominasi oleh jenis kelamin laki-laki dengan persentase 61,80 persen yaitu berjumlah 63 orang. Hal ini menandakan responden dengan jenis kelamin laki-laki lebih memilih membeli produk yang dimiliki oleh Karakter Kopi.

Sebagian besar konsumen yang membeli produk di Karakter Kopi didominasi pelajar/mahasiswa dengan jumlah konsumen 64 orang dengan persentase 62,70 . Hal ini menandakan bahwa responden yang lebih memilih membeli produk di Karakter Kopi adalah responden yang masih berstatus pelajar/mahasiswa.

Store Atmosphere adalah salah satu variabel yang dimasukkan dalam penelitian ini dan dijadikan sebagai variabel independen yang diukur dengan menggunakan 10 pernyataan indikator. Penelitian dilakukan setelah didapatkannya hasil penelitian responden terhadap variabel kualitas layanan yang lebih rinci dapat dilihat pada Tabel 3. 
Tabel 3.

Penilaian Responden terhadap variabel Store Atmosphere

\begin{tabular}{|c|c|c|c|c|c|c|c|c|}
\hline \multirow[t]{2}{*}{ Indikator } & \multicolumn{5}{|c|}{ Skor Jawaban } & \multirow{2}{*}{$\begin{array}{l}\text { Jumlah } \\
\text { Skor }\end{array}$} & \multirow{2}{*}{$\begin{array}{l}\text { Rata- } \\
\text { Rata }\end{array}$} & \multirow[b]{2}{*}{ Ket } \\
\hline & 1 & 2 & 3 & 4 & 5 & & & \\
\hline $\begin{array}{l}\text { Saya merasakan banguna luar } \\
\text { Karakter Kopi ini tampak } \\
\text { menarik }\end{array}$ & 0 & 11 & 17 & 43 & 31 & 400 & 3.92 & Baik \\
\hline $\begin{array}{l}\text { Menurut saya suasana } \\
\text { lingkungan dari Karakter Kopi } \\
\text { ini tampak indah }\end{array}$ & 0 & 14 & 14 & 45 & 29 & 387 & 3,79 & Baik \\
\hline Karakter Kopi ini sangat bersih & 0 & 8 & 25 & 41 & 28 & 395 & 3,87 & Baik \\
\hline $\begin{array}{l}\text { Musik di Karakter Kopi ini } \\
\text { membuat saya nyaman }\end{array}$ & 0 & 12 & 19 & 39 & 32 & 397 & 3.89 & Baik \\
\hline Fasilitas toko ini memadai & 0 & 14 & 17 & 35 & 36 & 399 & 3.91 & Baik \\
\hline $\begin{array}{l}\text { Tata letak ruangan di Karakter } \\
\text { Kopi ini nyaman }\end{array}$ & 0 & 10 & 22 & 38 & 32 & 398 & 3,90 & Baik \\
\hline $\begin{array}{l}\text { Tampilan informasi mengenai } \\
\text { menu yang dijual jelas }\end{array}$ & 0 & 9 & 24 & 36 & 33 & 399 & 3,91 & Baik \\
\hline $\begin{array}{l}\text { Penampilan produk Karakter } \\
\text { Kopi estetik (berseni) }\end{array}$ & 0 & 13 & 17 & 41 & 31 & 396 & 3,88 & Baik \\
\hline $\begin{array}{l}\text { Penampilan Karyawan di } \\
\text { Karakter Kopi ini baik }\end{array}$ & 0 & 17 & 13 & 29 & 43 & 404 & 3,96 & Baik \\
\hline \multirow{2}{*}{$\begin{array}{l}\text { Karyawan mempunyai } \\
\text { pengetahuan luas mengenai } \\
\text { produk toko ini }\end{array}$} & 0 & 10 & 22 & 31 & 39 & 405 & 3,97 & Baik \\
\hline & tal & & & & & 3980 & 3,90 & Baik \\
\hline
\end{tabular}

Sumber: Data diolah, 2018

Tabel 3 menunjukkan penilaian responden terhadap indikator-indikator dari variabel Store Atmosphere. Pernyataan tentang Karyawan mempunyai pengetahuan luas mengenai produk nilai rata-rata tertinggi yaitu 3,97 dan masuk dalam kriteria Baik. Hal ini berarti bahwa responden menganggap store atmosphere yang dimiliki Karakter Kopi mengenai karyawan mempunyai pengetahuan yang luas mengenai produk baik dirasakan oleh konsumen. Skor terendah yaitu 3,79 ditunjukkan pada indikator dengan pernyataan suasana lingkungan dari Karakter Kopi tampak indah. Hal ini berarti masih sedikit konsumen yang merasa suasa lingkungan dari Karakter Kopi tampak indah. Melihat data keseluruhan dari variabel Store Atmosphere, dapat ditentukan ratarata total dengan skor yaitu 3,90 maka dapat dinyatakan bahwa secara umum 
responden memiliki persepsi baik akan Store Atmosphere yang dimiliki oleh Karakter Kopi.

Variabel selanjutnya yang diteliti adalah Emosi, dimana variabel ini nantinya mempengaruhi perilaku pembelian dengan menggunakan 4 pernyataan indikator. Hasil penelitian responden terhadap variabel emosi dapat dilihat lebih rinci pada Tabel 4 berikut.

Tabel 4.

Penilaian Responden terhadap variabel Emosi

\begin{tabular}{|c|c|c|c|c|c|c|c|c|}
\hline \multirow[t]{2}{*}{ Indikator } & \multicolumn{5}{|c|}{ Skor Jawaban } & \multirow{2}{*}{$\begin{array}{c}\text { Jumlah } \\
\text { Skor }\end{array}$} & \multirow{2}{*}{$\begin{array}{l}\text { Rata- } \\
\text { Rata }\end{array}$} & \multirow[b]{2}{*}{ Ket. } \\
\hline & 1 & 2 & 3 & 4 & 5 & & & \\
\hline $\begin{array}{l}\text { Suasana di Karakter Kopi disini } \\
\text { mebuat saya merasa senang }\end{array}$ & 0 & 11 & 13 & 46 & 32 & 405 & 3,97 & Baik \\
\hline $\begin{array}{l}\text { Suasana di Karakter Kopi disini } \\
\text { membuat perasaan saya merasa } \\
\text { takjub }\end{array}$ & 0 & 9 & 28 & 44 & 21 & 383 & 3,75 & Baik \\
\hline $\begin{array}{l}\text { Suasana di Karakter Kopi ini } \\
\text { memuaskan perasaan saya }\end{array}$ & 0 & 15 & 14 & 45 & 28 & 392 & 3,84 & Baik \\
\hline $\begin{array}{l}\text { Suasana di Karakter Kopi ini } \\
\text { menarik perhatian saya }\end{array}$ & 0 & 14 & 16 & 42 & 30 & 394 & 3,86 & Baik \\
\hline Tota & & & & & & 1574 & 3,90 & Baik \\
\hline
\end{tabular}

Tabel 4 menunjukkan penilaian responden terhadap indikator-indikator dari variabel emosi. Tabel 4 menunjukkan bahwa pernyataan tentang suasana di Karakter Kopi menciptakan konsumen merasa senang memiliki nilai rata-rata tertinggi yaitu dengan skor 3,97 dan masuk dalam kriteria Baik, hal ini berarti responden merasa setuju bila suasana di Karakter Kopi menciptakan konsumen merasa senang. Sedangkan pernyataan dengan skor terendah yaitu 3,75 tenang suasana di Karakter Kopi menciptakan perasaan konsumen takjub. Hal ini berarti sedikit responden yang merasakan takjub saat berkunjung di Karakter Kopi. Melihat data keseluruhan dari variabel emosi, dapat ditentukan rata-rata total dengan skor yaitu 3,90 maka dapat dinyatakan bahwa secara umum responden 
memiliki persepsi baik terhadap emosi yang di rasakan saat berada di Karakter Kopi.

Perilaku Pembelian adalah variabel terakhir yang diteliti dalam penelitian ini, dimana variabel ini menjadi variabel dependen atau terikat yang dipengaruhi oleh Store Atmosphere dan emosi dengan menggunakan 3 pernyataan indikator untuk melihat penilaian responden terhadap variabel perilaku pembelian maka dapat dilihat pada Tabel 5.

Tabel 5.

Persepsi Responden terhadap variabel Perilaku Pembelian

\begin{tabular}{|c|c|c|c|c|c|c|c|c|}
\hline \multirow[t]{2}{*}{ Indikator } & \multicolumn{5}{|c|}{ Skor Jawaban } & \multirow{2}{*}{$\begin{array}{c}\text { Jumlah } \\
\text { Skor }\end{array}$} & \multirow{2}{*}{$\begin{array}{l}\text { Rata- } \\
\text { Rata }\end{array}$} & \multirow[b]{2}{*}{ Ket. } \\
\hline & 1 & 2 & 3 & 4 & 5 & & & \\
\hline $\begin{array}{l}\text { Saya merasa tertarik untuk } \\
\text { memilih produk pada Karakter } \\
\text { Kopi }\end{array}$ & 0 & 8 & 25 & 37 & 32 & 399 & 3.91 & Baik \\
\hline $\begin{array}{l}\text { Saya merasa nyaman untuk } \\
\text { bertahan di Karakter Kopi ini }\end{array}$ & 0 & 14 & 15 & 24 & 49 & 414 & 4.05 & Baik \\
\hline $\begin{array}{l}\text { Saya melakukan pembelian } \\
\text { berulang di Karakter Kopi ini }\end{array}$ & 0 & 15 & 14 & 34 & 39 & 403 & 3.95 & Baik \\
\hline Tot & & & & & & 1213 & 3,97 & Baik \\
\hline
\end{tabular}

Sumber: Data diolah, 2018

Tabel 5 menunjukkan penilaian responden terhadap indikator-indikator perilaku pembelian nilai rata-rata tertinggi yaitu pernyataan mengenai konsumen merasa nyaman untuk bertahan di Karakter Kopi dengan skor 4,05 dan masuk dalam kriteria Baik, hal ini berarti bahwa konsumen setuju dengan pernyataan mengenai konsumen merasa nyaman untuk bertahan di Karakter Kopi. Sedangkan pernyataan tentang konsumen merasa tertarik untuk memilih produk pada Karakter Kopi mendapatkan skor terendah yaitu 4,07. Hal ini berarti sedikit dari responden yang merasa tertarik untuk memilih produk pada Karakter Kopi. Melihat data keseluruhan dari variabel Perilaku pembelian, dapat ditentukan rata- 
rata total dengan skor yaitu 3,97 maka dapat dinyatakan bahwa perilaku pembelian konsumen pada Karakter Kopi ini baik.

Teknik analisis jalur digunakan sebagai teknik analisis data dalam penelitian ini.Teknik ini merupakan pengembangan lebih lanjut dari analisis regresi linear berganda yang menguji persamaan regresi, dimana variabel bebas dan terikat terlibat di dalamnya.

Tabel 6.

Hasil Analisis Jalur Persamaan Regresi 1

\begin{tabular}{|c|c|c|c|}
\hline Model & R Square & $\begin{array}{c}\text { Standardized Coefficients } \\
\text { Beta }\end{array}$ & Sig. \\
\hline Store Atmosphere & 0,582 & 0,763 & 0,000 \\
\hline
\end{tabular}

Berdasarkan hasil analisis jalur substruktural 1 yang disajikan pada tabel di atas, maka persamaan strukturalnya adalah sebagai berikut:

$$
M=0,763 X+e_{1}
$$

\section{Tabel 7.}

Hasil Analisis Jalur Persamaan Regresi 2

\begin{tabular}{lccc}
\hline \multicolumn{1}{c}{ Model } & R Square & $\begin{array}{c}\text { Standardized } \\
\text { Coefficients } \\
\text { Beta }\end{array}$ & Sig. \\
\hline Store Atmosphere & 0,800 & 0,300 & 0,000 \\
Emosi & & 0,644 & 0,000 \\
\hline \multicolumn{2}{c}{ Sumber: Data diolah, 2018} & &
\end{tabular}

Berdasarkan hasil analisis jalur substruktural 2 yang disajikan pada tabel di atas, maka persamaan strukturalnya adalah sebagai berikut:

$$
\mathrm{Y}=0,300 \mathrm{X}+0,644 \mathrm{M}+\mathrm{e}_{2}
$$

Pengaruh tidak langsung serta pengaruh total antar variabel dirangkum dalam Tabel 8. 
Tabel 8.

Pengaruh Langsung dan Pengaruh Tidak Langsung serta Pengaruh Total

\begin{tabular}{lccc}
\hline $\begin{array}{c}\text { Pengaruh } \\
\text { Variabel }\end{array}$ & $\begin{array}{c}\text { Pengar } \\
\text { uh Langsung }\end{array}$ & $\begin{array}{c}\text { Pengaruh Tidak } \\
\text { Langsung Melalui Mediasi } \\
\left(\boldsymbol{\beta}_{\mathbf{1}} \mathbf{x} \boldsymbol{\beta}_{\mathbf{3}}\right)\end{array}$ & $\begin{array}{c}\text { Pengaruh } \\
\text { Total }\end{array}$ \\
\hline $\mathrm{X} \rightarrow \mathrm{M}$ & 0,763 & - & 0,763 \\
$\mathrm{M} \rightarrow \mathrm{Y}$ & 0,644 & - & 0,644 \\
$\mathrm{X} \rightarrow \mathrm{Y}$ & 0,300 & 0,229 & 0,529 \\
\hline Sumber: Data diolah, 2018 & \multicolumn{2}{l}{}
\end{tabular}

Berdasarkan model substruktural 1 dan substruktural 2, maka dapat disusun model diagram jalur akhir. Sebelum menyusun model diagram jalur akhir, terlebih dahulu dihitung nilai standar eror sebagai berikut:

$$
\begin{aligned}
& \text { Pei }=\sqrt{1-\mathrm{Ri}^{2}} \text {. } \\
& \mathrm{Pe}_{1}=\sqrt{1-\mathrm{R}_{1}^{2}}=\sqrt{1-0,562^{2}}=0,662 \\
& \mathrm{Pe}_{2}=\sqrt{1-\mathrm{R}_{2}{ }^{2}}=\sqrt{1-0,800^{2}}=0,447
\end{aligned}
$$

Berdasarkan perhitungan nilai standar eror, didapatkan hasil $\mathrm{Pe}_{1}$ atau standar eror variabel emosi sebesar 0,662 dan $\mathrm{Pe}_{2}$ atau standar eror variabel perilaku pembelian sebesar 0,447 . Hasil koefisien determinasi total dihitung sebagai berikut:

$$
\begin{aligned}
& \mathrm{R}^{2} \mathrm{~m}=1-\left(\mathrm{Pe}_{1}\right)^{2}\left(\mathrm{Pe}_{2}\right)^{2} \\
& =1-(0,662)^{2}(0,447)^{2} \\
& =0,912
\end{aligned}
$$

Nilai determinasi total sebesar 0,912 mempunyai arti bahwa sebesar 91,2\% variasi perilaku pembelian dipengaruhi oleh variasi Store Atmosphere dan emosi, sedangkan sisanya sebesar $8,8 \%$ dijelaskan oleh faktor lain yang tidak dimasukkan ke dalam model. 
Uji sobel dilakukan dengan cara menguji kekuatan pengaruh tidak langsung variabel bebas (X) ke variabel terikat (Y) melalui variabel mediasi (M). Menguji signifikansi pengaruh tidak langsung Store Atmosphere dengan perilaku pembelian melalui emosi, maka dapat dipergunakan substitusi nilai:

$$
a=0,311 ; S_{a}=0,026 ; b=0,499 ; S_{b}=0,054
$$

Maka didapat nilai $\mathrm{z}$ hitung $=5,4084$

Jika nilai z hitung lebih besar dari z tabel, maka dapat disimpulkan terjadi pengaruh mediasi. Berdasarkan perhitungan, didapatkan nilai $\mathrm{z}$ hitung sebesar 5,4084 yang artinya lebih besar dari z tabel yaitu $1,9842(5,4084>1,9842)$. Dapat disimpulkan bahwa emosi mampu memediasi pengaruh Store Atmosphere terhadap perilaku pembelian.

Berdasarkan hasil analisis pengaruh Store Atmosphere terhadap emosi diperoleh nilai koefisien beta sebesar 0,763 dengan tingkat signifikansi sebesar 0,000 ( $₫, 05$ ) yang berarti $\mathrm{H}_{0}$ ditolakdan $\mathrm{H}_{1}$ diterima. Hasil tersebut berarti bahwa variabel Store Atmosphere berpengaruh positif dan signifikan terhadap emosi. Jadi semakin baik Store Atmosphere yang dimiliki oleh Karakter Kopi, maka akan semakin berpengaruh dalam menciptakan emosi positif konsumen.

Hasil penelitian ini sejalan dengan hasil penelitian sebelumnya yang dilakukan oleh Feng et al. (2008), Helmefalk dan Hultēn. (2017), Mishra et al. (2014), Tunjungsari dkk. (2016), Pragita dkk. (2013), Sukma dkk. (2012), Madjid (2014) yang menyatakan bahwa Store Atmosphere berpengaruh positif dan signifikan terhadap emosi 
Berdasarkan hasil analisis pengaruh emosi terhdap perilaku pembelian diperoleh nilai koefisien beta sebesar 0,644 dengan tingkat signifikansi sebesar 0,000 ( $₫, 05)$ yang berarti $\mathrm{H}_{0}$ ditolakdan $\mathrm{H}_{1}$ diterima. Hasil tersebut berarti bahwa variabel Store Atmosphere berpengaruh positif dan signifikan terhadap emosi. Jadi semakin baik penciptaan emosi yang dapat dilakukan oleh Karakter Kopi, Maka akan semakin berpengaruh kepada perilaku pembelian konsumen.

Hasil penelitian ini sejalan dengan hasil penelitian sebelumnya yang dilakukan oleh Feng et al. (2008), Setiawan (2015), Makarawung dkk. (2014) yang menyatakan bahwa emosi berpengaruh positif dan signifikan terhadap perilaku pembelian

Berdasarkan hasil analisis pengaruh emosi terhdap perilaku pembelian diperoleh nilai koefisien beta sebesar 0,300 dengan tingkat signifikansi sebesar $0,000(\$, 05)$ yang berarti $\mathrm{H}_{0}$ ditolak dan $\mathrm{H}_{1}$ diterima. Hasil tersebut berarti bahwa variabel Store Atmosphere berpengaruh positif dan signifikan terhadap emosi. Jadi semakin baik Store Atmosphere yang dimiliki oleh Karakter Kopi, maka akan semakin berpengaruh kepada perilaku pembelian konsumen.

Hasil penelitian ini sejalan dengan hasil penelitian sebelumnya yang dilakukan oleh Feng et al. (2008), Helmefalk dan Hultēn. (2017), Mishra et al. (2014), Andersson et al. (2012), Fuad (2010), yang menyatakan bahwa Store Atmosphere berpengaruh positif dan signifikan terhadap perilaku pembelian

Pengujian hipotesis pada emosi memediasi Store Atmosphere terhadap perilaku pembelian dengan menggunakan uji Sobel membuktikan peran emosi 
memediasi Store Atmosphere terhadap perilaku pembelian dengan hasil $\mathrm{Z}=$ $5,4084>1,9842$ dengan tingkat signifikansi $0,000<0,05$.

Hasil penelitian ini didukung oleh penelitian sebelumnya yang dilakukan oleh Yoo et al. (1998) dalam Feng et al. (2008:99) menyatakan bahwa "A plethora of research has confirmed the role of emotion as an important mediator between Store Atmosphere and consumer behavior". Kebanyakan dari penelitian telah menerima peran emosi sebagai faktor penting sebagai mediator antara atmosfer toko dan perilaku pembelian. Pada penelitian ini, ditemukan Emosi terbukti mampu memediasi secara positif dan signifikan pengaruh antara Store Atmosphere terhadap perilaku pembelian.

Berdasarkan hasil yang diperoleh dalam penelitian ini, terdapat beberapa implikasi yang dihasilkan. Pertama, di dalam variabel Store Atmosphere didapat hasil bahwa indikator (Participant) "karyawan memiliki sikap yang baik dan memiliki pengetahuan yang luas" menjadi indikator yang memiliki nilai rata-rata tertinggi dibandingkan indikator lainnya, hal ini berarti bila kariyawan bersikap yang baik dan memiliki pengetahuan yang luas maka akan sangat berpengaruh kepada perilaku pembelian dari konsumen yang datang. dengan demikian Karakter Kopi harus mempertahankan Participant yang dimiliki oleh para karwayan dan terus meningkatkan faktor-faktor lainnya seperti Eksterior, Interior, Designlayout dan Display yang sudah dimiliki.

Implikasi kedua yaitu dalam variabel Emosi yang di dapatkan hasil bahwa indikator "suasana di Karakter Kopi membuat konsumen merasa senang" menjadi indikator yang memiliki nilai rata-rata paling tinggi dibandingkan indikator yang 
lainnya dalam variable tersebut. Hal ini berarti suasana yang dimiliki oleh Karakter kopi yang dapat menciptakaan perasaan senang kepada konsumen akan mempengaruhi perilaku pembelian konsumen tersebut.

Patut disadari bahwa terdapat beberapa keterbatasan dari penelitian ini adalah ruang lingkup penelitian terbatas pada wilayah Kota Denpasar, sehingga hasil penelitian ini tidak dapat digeneralisasi untuk konsumen diluar wilayah Kota Denpasar.

Jumlah responden yang terbatas dalam penelitian dikarenakan keterbatasan biaya dan waktu yang tersedia dan hanya dari lingkungan PT. BPR Bali Dananiaga, sehingga hasil penelitian ini hanya dapat diterapkan dilingkungan Karakter Kopi dan tidak dapat digeneralisir pada lingkungan coffee shop lain. Mengingat penelitian ini dilakukan dalam jangka waktu yang cukup singkat sedangkan lingkungan dapat berubah setiap saat, yang menyebabkan penelitian ini penting untuk dilakukan kembali.

\section{SIMPULAN DAN SARAN}

Berdasarkan pembahasan hasil penelitian yang telah dilakukan, maka dapat disimpulkan bahwa store atmosphere berpengaruh positif dan signifikan terhadap Emosi. Hal ini berarti semakin baik Store Atmosphere yang di miliki oleh Karakter Kopi, maka semakin ampuh menciptakan emosi positif pada konsumen Karakter kopi.

Emosi berpengaruh positif dan signifikan terhadap perilaku pembelian. Hal ini berarti semakin terciptanya emosi positif yang dirasakan oleh konsumen, maka semakin meningkatkan Perilaku pembelian konsumen pada Karakter kopi. Store 
Atmosphere berpengaruh positif dan signifikan terhadap Perilaku pembelian konsumen. Hal ini berarti semakin baik Store Atmosphere yang dimiliki semakin meningkatnya perilaku pembelian konsumen pada karakter kopi.

Emosi Positif mampu memediasi hubungan Store Atmosphere terhadap perilaku pembelian konsumen. Hal ini berarti bahwa emosi positif yang mampu di rasakan oleh konsumen di Karakter kopi turut mempengaruhi Store Atmosphere terhadap perilaku pembelian konsumen pada Karakter Kopi.

Saran yang dapat di berikan berkaitan dengan penelitian ini sebagai bahan pertimbangan serta masukan yang berguna bagi owner Karakter Kopi untuk selanjutnya adalah untuk meningkatkan Store Atmosphere yang dimiliki supaya lebih mengikat konsumen untuk datang adalah lebih memperindah lingkungan sekitar Karakter kopi tersebut, dengan cara menanam beberapa tanaman dan rumput disekitar halaman Karakter kopi. Karena dari hasil penelitian ini dapat di liat bahwa indikator ini memiliki skor yang rendah yaitu 3,79.

Untuk menigkatkan penciptaan emosi positif yang dapat di rasakan oleh konsumen yang datang, selain dengan memperindah lingkungkan sebaiknya juga menambahkan beberapa hiasan pada halaman yang sesuai dengan konsep rumah panggung yang dimiliki oleh Karakter kopi tersebut, sehingga konsumen dapat merasa takjub saat datang, karena dari hasil penelitian ini indikator yang ini memiliki skor yang rendah yaitu 3,75 .

Untuk memaksimalkan pembelian konsumen yang datang ke Karakter kopi, dapat dengan cara menambahkan produk yang dijual bukan hanya kopi tetapi produk-produk yang lain seperti makanan dan minuman selain kopi, sehingga 
konsumen yang tidak suka meminum kopi juga dapat tertarik untuk membeli produk di Karakter kopi, karena dari hasil penelitian ini indikator yang ini memiliki skor yang rendah yaitu 3,91.

Bagi peneliti selanjutnya, diharapkan untuk melakukan penelitian dengan cakupan yang lebih luas seperti: mencari lokasi penelitian selain coffee shop, menggunakan sampel penelitian yang lebih banyak, menambah variabel-variabel lain diluar penelitian ini, menggunakan teknik analisis data yang berbeda (PLS atau SEM), serta diharapkan mampu menambah refrensi terhadap variabel yang akan diteliti.

\section{REFERENSI}

Andersson, Pernille K, Per Kristensson, Erik Wästlund, and Anders Gustafsson. 2012. Let the music play or not: the influence of background music on consumer behavior. Journal of Retailing and Consumer Services.19(2012) 6: 553-560.

A.W Marsum. 2005. Restoran dan Segala Permasalahannya, Edisi IV. Yogyakarta: Andi.

Belch, G. \& Belch, M. 2012. Advertising and Promotion (An Integrated Marketing Communications Perspective) Global Edition. New York: McGraw-Hill Irwin.

Feng, Chuan Pan, Suh-Jean Su, and Che-Chao Chiang. 2008. Dual attractiveness of winery: atmospheric cues on purchasing. International Journal of Wine Business Research. Vol. 20 Iss 2 pp. $95-110$.

Fuad, Muhammad. 2010. Store Atmosphere Dan Perilaku Pembelian Konsumen Di Toko Buku Gramedia Malang. Jurnal Manajemen Pemasaran Modern. Vol. 2. No. 1.

Goleman, Daniel. 2000. Working With Emotional Intelligence (terjemahan). Jakarta : PT. Gramedia Pustaka Utama.

Helmefalk, Miralem and Bertil Hultén. 2017. Multi-sensory congruent cues in designing retail Store Atmosphere: Effects on shoppers' emotions and purchase behavior. Journal of Retailing and Consumer Services 38. 1-11. 
Kotler, Philip dan Kevin Lane Keller. 2009. Manajemen Pemasaran. Diterjemahkan Oleh : Bob Sabran. Jilid 2. Edisi 13. Jakarta: Penerbit Erlangga.

2012. Marketing Management. 14th edition. United States of America: Pearson Education

Madjid, Rahmat. 2014. The Influence Store Atmosphere Towards Customer Emotions and Purchase Decisions. International Journal of Humanities and Social Science Invention. Volume. 3. Issue. 10. pp. 11-19.

Makarawung, Evanglin M. Peggy A Mekel, and Maria V. J. Tielung. 2014. Analyzing The Effect Of Consumers Emotions On Consumer Behavior At Matahari Department Store Manado. Jurnal EMBA.Vol.2 No.3 Hal. 779788.

Mishra, Hari Govind, Piyush Kumar Sinha, and Surabhi Koul. 2014. Impact of Store Atmospherics on Customer Behavior: Influence of Response Moderators. Journal of Business and Management. Vol. 20, No. 1. pp. 4565

Mowen, Jhon C. dan Minor, Michael. 2002. Perilaku Konsumen. Jilid Pertama. Alihbahasa: Lina Salim. Jakarta: Erlangga.

Olahut, Made Roxana, Jaafar El_Murad, and Ioan Plalas. 2012. Store Atmosphere: Conceptual Issues and It's Impact on Shopping Behavior. International Conference "Marketing - from information to decision" 5th Edition.

Pragita, Atika Ayu , Achmad Fauzi DH, dan Srikandi Kumadji. 2013. Pengaruh Store Atmosphere (Suasana Toko) Terhadap Emosi Dan Dampaknya Kepada Keputusan Pembelian (Survei pada Pengunjung Baker's Kings di Mall Olimpic Garden Malang). E-Journal fakultas Ilmu Administrasi Universitas Brawijaya. Volume. 7. No. 1. Hal. 1-11

Santos, Eduardo Biagi Almeida and Otávio Bandeira De Lamônica Freire. 2013. The Influence Of Music On Consumers Purchase Behavior In Retail Environment. Independent Journal Of Management \& Production (IJM\&P). Vol. 4. No. 2. pp. 537-548

Setiawan, Ronni Stefan. 2015. Atmosfer Toko, Emosi Konsumen Perilaku Pembelian Pada Toko Roti. Jurnal Fakultas Ekonomi Universitas Atma Jaya Yogyakarta.

Sherman, Elaine, Anil Mathur, dan Ruth Belk Smith. 1997. Store Environment And Cosumer Purchase Behacior, Mediating Role Of Consumer Emotions. Psychology \& Marketing Vol.14(4):361-378.

Spies, Kordelia , Friedrich Hesse, and Kerstin Loesch. Store Atmosphere, Mood and Purchasing Behavior. intern. J. of Research in Marketing. 14 1997 1-17. 
Sukma, Erlangga Andi, Achmad Fauzi DH, dan Fransisca Yaningwati. 2012. Suasana Toko Dalam Menciptakan Emosi Dan Pengaruhnya Terhadap Keputusan Pembelian (Survey Pada Pengunjung Retal Hypermart Malang Town Square Kota Malang). E-Journal fakultas Ilmu Administrasi Universitas Brawijaya. Vol. 6. No. 1. Hal. 60-87

Sugiyono. 2017. Metode Penelitian Kuantitatif, Kualitatif, dan R\&D. Bandung: Alfabeta

Summersa, Teresa A And Paulette R. Hebertb. 2001. Shedding some light on store atmospherics Influence of illumination on consumer behavior. Journal of Business Research.

Tunjungsari, Septian Vety, Achmad Fauzi DH, dan M.Kholid Mawardi. 2016. Pengaruh Store Atmosphere (Suasana Toko) Terhadap Emosi Serta Dampaknya Pada Keputusan Pembelian (Survei pada Pembeli di Ria Djenaka Cafe dan Resto, Kota Batu). Jurnal Administrasi Bisnis (JAB). Vol. 30 No. 1. Hal. 1-7

Turley, L. W. and Ronald E Milliman. 2000. Atmosphere Effects on Shopping Begavior: A Review of The Experimental Evidence. Journal of Business Research 49 193-211.

Utami, Christina Whidya. 2006. Manajemen Ritel: Strategi dan Implementasi Modern. Edisi Pertama. Jakarta: Salemba Empat. 